\title{
Transforming Growth Factor- $\beta$ Regulates the Growth of Valve Interstitial Cells in Vitro
}

\author{
Chen Li and Avrum I. Gotlieb \\ From the Toronto General Research Institute and Laboratory \\ Medicine Program, University Health Network and the \\ Department of Laboratory Medicine and Pathobiology, \\ University of Toronto, Toronto, Ontario, Canada
}

\begin{abstract}
Although valve interstitial cell (VIC) growth is an essential feature of injured and diseased valves, the regulation of VIC growth is poorly understood. Transforming growth factor (TGF)- $\beta$ promotes VIC proliferation in early-stage wound repair; thus, herein, we tested the hypothesis that TGF- $\beta$ regulates VIC proliferation under normal nonwound conditions using low-density porcine VIC monolayers. Cell numbers were counted during a 10-day period, whereas proliferation and apoptosis were quantified by bromodeoxyuridine staining and TUNEL, respectively. The extent of retinoblastoma protein phosphorylation and expression of cyclin D1, CDK 4, and p27 were compared using Western blot analysis. Adhesion was quantified using a trypsin adhesion assay, and morphological change was demonstrated by immunofluorescence localization of $\alpha$-smooth muscle actin and vinculin. TGF- $\beta$-treated VICs were rhomboid; significantly decreased in number, proliferation, and retinoblastoma protein phosphorylation; and concomitantly had decreased expression of cyclin D1/CDK4 and increased expression of p27. TGF$\beta$-treated VICs adhered better to substratum and had more vinculin plaques and $\alpha$-smooth muscle actin stress fibers than did controls. Thus, the regulation of VIC growth by TGF- $\beta$ is context dependent. TGF- $\beta$ prevents excessive heart valve growth under normal physiological conditions while it promotes cell proliferation in the early stages of repair, when increased VICs are required. (AmJ Pathol 2011, 179:1 746-1755; DOI: 10.1016/j.ajpath.2011.06.007)
\end{abstract}

Valve interstitial cells (VICs) are present in all three layers $^{1,2}$ of the adult heart valve and are the most prevalent cell type present. ${ }^{3-5}$ They are situated underneath the surface endocardium ${ }^{1}$ and embedded in an extracellular matrix (ECM) that they secrete and actively remodel. ${ }^{5}$ VICs are the master cells within the valve because they regulate both physiological and pathological processes. $^{2,6}$ In their quiescent state, VICs show characteristics of fibroblasts and are critical for the maintenance of normal valve structure and function. ${ }^{2,5}$ During development or in response to injury and disturbed hemodynamic flow, VICs become activated ${ }^{2,6,7}$ and take on features of myofibroblasts. ${ }^{2,5-7}$ Activated VICs are characterized by increased $\alpha$-smooth muscle actin $(\alpha-$ SMA) expression, stress fiber formation, contractility, and proteolytic enzyme secretion. ${ }^{2,4,6-8}$ Like other myofibroblasts, ${ }^{9}$ VICs regulate wound repair, as demonstrated by the increased number and enhanced production of ECM components, both in diseased valves and in in vitro wound models. ${ }^{10,11}$ Thus, understanding the regulation of the biological and pathobiological features of VICs is essential for understanding the pathogenesis of heart valve diseases.

Quiescent VICs are activated by several cytokines and growth factors, one of them being transforming growth factor (TGF)- $\beta,{ }^{2,12}$ a $25-\mathrm{kD}$ a protein of the TGF- $\beta$ superfamily. ${ }^{13}$ The TGF- $\beta$ ligand binds and brings together TGF- $\beta$ receptor I (TGF- $\beta$ RI) and TGF- $\beta$ RII Ser-Thr kinases. ${ }^{14}$ TGF- $\beta$ RII phosphorylates TGF- $\beta$ RI (also known as ALK5) and propagates the signal through phosphorylation of Smad proteins or via non-Smad mechanisms, such as mitogen-activated protein kinase, $\rho$-like RhoGTPase, and phosphatidylinositol 3-kinase (PI3K)-AKT pathways. ${ }^{14,15}$ TGF- $\beta$ regulates a wide range of cellular processes, including cell proliferation, apoptosis, differentiation, migration, and ECM remodeling. ${ }^{8,12,14,16}$ This multifunctionality allows TGF- $\beta$ to participate in wound repair in multiple tissues and organs of the body. ${ }^{12,17}$ Overexpression of TGF- $\beta$ is often observed in in vivo

Supported by grants from the Heart and Stroke Foundation of Ontario (NA6204) and the Canadian Institute for Health Research (MOP84228) and an Undergraduate Life Science Award from the University of Toronto (C.L.).

Accepted for publication June 15, 2011.

Address reprint requests to Avrum I. Gotlieb, M.D.C.M., F.R.C.P.C., Senior Academic Advisor to the Dean, Medical Sciences Building, 1 King's College Circle, Room 2113B, University of Toronto, Toronto, ON, Canada M5S 1A8. E-mail: avrum.gotlieb@utoronto.ca. 
wound sites. ${ }^{12}$ It is also present in several heart valverelated diseases (eg, calcific aortic stenosis, ${ }^{18,19}$ mitral valve prolapse, ${ }^{20,21}$ and Marfan syndrome). ${ }^{22}$ By using a well-characterized wound model, ${ }^{11}$ we also reported an up-regulation of TGF- $\beta$ at the in vitro wound edge. The exogenous addition of TGF- $\beta$ further activates the VICs along the wound edge and stimulates their proliferation to enhance wound closure within the first 24 hours after wounding. ${ }^{8}$

Although the beneficial role of TGF- $\beta$ in wound repair has been studied, its effects on cell growth remain controversial, owing to its context-dependent nature. Depending on TGF- $\beta$ concentration, ${ }^{23,24}$ cell type of interest, ${ }^{25}$ and degree of cell differentiation, ${ }^{26}$ varying responses in proliferation and apoptosis have been reported. Because VIC growth in vitro is poorly understood, we investigated the regulation of VIC proliferation by TGF- $\beta$.

\section{Materials and Methods}

\section{VIC Growth Curve}

VICs were harvested from porcine heart valve explants, as previously described. ${ }^{1} \mathrm{VICs}$ at passages 3 to 5 were plated in triplicate $35-\mathrm{mm}$ tissue culture dishes (Falcon; BD Biosciences, San Jose, CA) at a density of 2000 cells $/ \mathrm{cm}^{2}$ and cultured in $2 \mathrm{~mL}$ of $5 \%$ fetal bovine serum containing media. Porcine TGF- $\beta 1$ (R\&D Systems, Minneapolis, MN) was reconstituted in a vehicle solution of 4 $\mathrm{mmol} / \mathrm{L} \mathrm{HCl}$ and $0.1 \%$ bovine serum albumin. Media containing the vehicle solution or active porcine TGF- $\beta 1$ ( 0.1 , 0.5 , or $5 \mathrm{ng} / \mathrm{mL}$ ) were first added to cultures 18 hours after plating and every 2 days thereafter. Cell counts were performed in triplicate during a 10-day period using the Countess Automated Cell Counter (Invitrogen, Eugene, OR) at 18, 42, and 66 hours after plating and then every 2 days.

In an attempt to rescue the TGF- $\beta$-mediated reduction in cell number, both a neutralizing antibody and a potent receptor inhibitor were used. TGF- $\beta$-neutralizing antibody (R\&D Systems) was reconstituted in sterile PBS to a $10-\mathrm{mg} / \mathrm{mL}$ stock solution. At 18 hours after plating and every 2 days thereafter, media containing $15-\mu \mathrm{g} / \mathrm{mL}$ neutralizing antibody was added to the culture. SB431542 is a potent inhibitor of TGF- $\beta$ RI. ${ }^{27-29}$ Solid anhydrous SB431542 (Sigma, St Louis, MO) was dissolved in sterile dimethyl sulfoxide (DMSO) and prepared into a 10 $\mathrm{mmol} / \mathrm{L}$ stock solution. A specific amount of the stock solution was added to the culture media to achieve desired further dilutions. In experiments involving SB431542 treatment alone, media containing DMSO or 1 to approximately $10 \mu \mathrm{mol} / \mathrm{L}$ of SB431542 were added to the cell cultures, as previously described. For the experiments involving both SB431542 and TGF- $\beta 1$, VICs were pretreated with the inhibitor 2 hours before the addition of TGF- $\beta 1$. Cell counts were performed in triplicate during a 10-day period using a Coulter counter (Coulter Electronics Inc., Hialeah, FL) at the time points previously specified. To confirm the results of SB431542 inhibition,
SD208 (Tocris Bioscience, Bristol, UK) was used. SD208 is also a potent and selective inhibitor of TGF- $\beta$ RI. ${ }^{30}$ Preparation and treatment with SD208 follows the previously mentioned procedure for SB431542.

\section{Immunofluorescent Staining}

VICs were plated on $22 \times 22-\mathrm{mm}$ square glass coverslips (Fisher Scientific, Pittsburgh, PA) in 35-mm tissue culture dishes at a density of $2000 \mathrm{cell} / \mathrm{s} / \mathrm{cm}^{2}$ and cultured under the same conditions as previously described. Vehicle and TGF- $\beta$-treated monolayers were immunofluorescently stained 4 or 6 days after first addition of TGF- $\beta$. Briefly, VICs on glass coverslips were fixed with methanol-acetone $(1: 1)$ at $4^{\circ} \mathrm{C}$ (in the case of $\alpha$-SMA) or $4 \%$ paraformaldehyde (Electron Microscopy Sciences, Fort Washington, PA) [in the case of vinculin and phosphorylated Smad ( $p-S m a d)]$, rinsed three times with PBS for 5 minutes in tissue culture dishes, permeabilized with $0.1 \%$ Triton X-100 (Sigma) in PBS for 3.5 minutes (in the case of $\alpha$-SMA and p-Smad) or with $0.2 \%$ Triton X-100 in PBS for 5 minutes (in the case of vinculin), and rinsed again three times in PBS at 5-minute intervals. The coverslips were incubated with mouse anti- $\alpha$-SMA (1:400; Sigma), mouse anti-vinculin (1:50; Sigma), and rabbit anti-p-Smad2/3 (Ser423/425) (1:50; Santa Cruz Biotechnology, Santa Cruz, CA) primary antibodies at room temperature for 1 hour and were then washed three times with PBS at 5 -minute intervals. Secondary antibodies were goat antimouse and goat anti-rabbit Alexa 488 (1:200; Molecular Probes, Invitrogen, Eugene, OR). Hoechst 33342 (1: 2000; Lonza, Basel, Switzerland) was used to counterstain nuclei. After a 20-minute incubation with secondary antibody, coverslips were dipped in deionized water, mounted with Prolong Gold antifade reagent (Molecular Probes, Invitrogen), and stored at $4^{\circ} \mathrm{C}$. Coverslips were examined using $\times 10$ and $\times 60$ objectives of an Olympus FluoView 1000 Laser Scanning Confocal Microscope (Olympus, Markham, ON, Canada) equipped with lasers providing exciting wavelengths of 405 and $488 \mathrm{~nm}$, respectively. Serial optical sections were obtained at $0.1-\mu \mathrm{m}$ intervals for a total of 4.5 to $8.5 \mu \mathrm{m}$. Images were captured at randomly selected regions using FV10-ASW 1.6 software (Olympus) to avoid saturation.

\section{Quantification of Apoptosis}

TUNEL was performed using the TACS TdT-fluorescein in situ apoptosis detection kit (R\&D Systems) to identify apoptotic VICs. Total nuclei were counterstained with Hoechst. A positive and a negative control were used for comparison.

\section{Quantification of Proliferation}

Bromodeoxyuridine (BrdU) labeling reagent (Amersham Sciences, Buckinghamshire, UK) was added in 1:1000 dilution to vehicle and TGF- $\beta$-treated cultures 2 and 4 days after first treatment at the time of media change and incubated for 6 hours. The coverslips were then washed in PBS, fixed in ethanol-acetic acid (95:5) for 20 minutes 
at $4^{\circ} \mathrm{C}$ in a coplin jar, and denatured with $2 \mathrm{~N} \mathrm{HCl}$ for 30 minutes in an incubator at $37^{\circ} \mathrm{C}$. Incubation for 1 hour with mouse anti-BrdU (1:1000; Sigma) primary antibodies at $37^{\circ} \mathrm{C}$ was followed by secondary antibody, as previously described. VIC nuclei were counterstained with propidium iodide (1:1000; Sigma). Images were captured using the $\times 20$ objective of a Nikon TE300 (Nikon, Melville, NY) inverted fluorescence microscope, starting two fields away from the left top corner, taking every other field until the whole coverslip was covered. A total of 15 fields were captured for each coverslip, with approximately 200 to 500 cells and 30 to 100 cells per fields for vehicle and TGF- $\beta$-treated monolayers, respectively. The total number of nuclei was counted using Simple PCI 6.5 (Hamamatsu, Shizuoka Prefecture, Japan), and the number of BrdU-stained nuclei was counted manually. Proliferation was quantitated as the percentage of labeled cells in the total number of cells counted.

\section{Trypsin Adhesion Assay}

By using a previously characterized trypsin adhesion assay ${ }^{31}$ with slight modification, the degree of adhesiveness to the substratum was compared. Briefly, vehicle or TGF- $\beta$-treated VICs were incubated in $1.0 \mathrm{~mL}$ of $1: 10$ diluted trypsin-EDTA (Invitrogen) for 0.5 or 1.0 minutes, followed by immediate neutralization with $0.5 \mathrm{~mL}$ of media containing $5 \%$ fetal bovine serum. The number of VICs that were detached during the incubation period was counted using a Coulter counter. The remaining VICs in the monolayer were washed three times with PBS, detached using full trypsin-EDTA, and counted. The percentages of vehicle or TGF- $\beta$-treated VICs detached during the incubation period were compared.

\section{Western Blot Analyses}

To harvest enough cells for protein extraction, TGF- $\beta$ - or SB431542-treated VICs and their respective controls were cultured in 100-mm tissue culture dishes (Falcon) until they reached confluency. Whole cell protein extracts were obtained by lysing the VICs in ice-cold radioimmunoprecipitation assay buffer (50 mmol/L Tris, pH7.4; 150 $\mathrm{mmol} / \mathrm{L} \mathrm{NaCl} ; 1 \%$ Triton; $0.25 \%$ Na-deoxycholate; and 1 $\mathrm{mmol} / \mathrm{L}$ EDTA) supplemented with protease inhibitor (Roche Applied Science, Indianapolis, IN), 1 mmol/L sodium orthovanadate, $1 \mathrm{mmol} / \mathrm{L}$ phenylmethylsulfonyl fluoride, and $1 \mathrm{mmol} / \mathrm{L}$ sodium fluoride (Sigma). Nuclear and cytosolic protein extracts were obtained using the NE-PER Nuclear and Cytoplasmic Extraction Reagents (Thermo Scientific, Rockford, IL), supplemented with protease inhibitor (Roche Applied Science), $1 \mathrm{mmol} / \mathrm{L}$ sodium orthovanadate, $1 \mathrm{mmol} / \mathrm{L}$ phenylmethylsulfonyl fluoride, and $1 \mathrm{mmol} / \mathrm{L}$ sodium fluoride, following the extraction protocols specified by the kit. The protein concentration was determined by Bradford analysis, and 10 to $40 \mu \mathrm{g}$ of protein per lane was resolved by SDS-PAGE. Transfer and blotting were performed on an iBlot gel transfer device (Invitrogen) and a SNAP i.d. protein detection system (Millipore, Danvers, MA), following the instructions specified. The blots were reacted with rabbit anti-phosphorylated retinoblastoma protein (pRb) (Ser807/811) (1:200), mouse anti- $\alpha$-SMA (1:5000), anticyclin D1 (1:100), anti-CDK4 (1:200), and anti-p27 (1: 100) (Santa Cruz Biotechnology). Mouse anti- $\beta$-tubulin (1:5000; Sigma) and anti-histone H1 (1:5000; Millipore) antibodies were used to confirm equal protein loading in the whole cell/cytosolic and nuclear portion, respectively. Goat anti-mouse and goat anti-rabbit secondary antibodies (horseradish peroxidase conjugated), at a dilution of 1:5000, were used. The immune complexes were detected using Luminata Western HRP Substrates (Millipore).

The intensities of protein bands were quantified and compared using Image J 1.43 (US NIH, Bethesda, MA). The densitometric data were normalized such that the group that has a higher expression level is set at 100 .

\section{Statistical Analysis}

The Student's $t$-test was used to compare vehicle with TGF- $\beta 1$-treated groups. $P<0.05$ was considered significant. All statistical analyses were performed using GraphPad Prism version 5 software (GraphPad Software Inc., San Diego, CA).

\section{Results}

\section{TGF- $\beta$ Treatment Significantly Inhibits the Increase in VIC Number over Time}

Staining for the $\mathrm{p}$-Smad2/3 complex, a key complex involved in TGF- $\beta$ signaling, is used to confirm activation of the pathway. At both 4 and 6 days after treatment, TGF$\beta$-treated VICs (Figure 1, B and D) showed significantly more prominent $\mathrm{p}$-Smad nuclear localization (Figure 1E) compared with the control, in which nuclei are only faintly stained (Figure 1, A and C).

Under phase-contrast microscopy, the vehicle and TGF- $\beta$-treated VICs initially showed no observable difference in cell density or morphological features (Figure 2, A-D). After 4 days, treatment with TGF- $\beta$ resulted in a significant reduction in VIC density (Figure 2, E-J). Although vehicle-treated VICs became superconfluent 8 days after treatment, TGF- $\beta$-treated VICs failed to reach confluency, even when they were cultured for up to 12 days. Instead, prolonged treatment caused VICs to cluster and form nodules. The growth of TGF- $\beta$-treated VICs leveled off after 4 days of treatment, whereas that of the vehicle-treated cells remained in the log phase. The inhibitory effect is concentration dependent, as shown in Figure 3A. Maximal inhibition was observed with 0.5 $\mathrm{ng} / \mathrm{mL}$ TGF- $\beta$ treatment because a higher concentration $(5 \mathrm{ng} / \mathrm{mL}$ ) resulted in the same extent of inhibition (data not shown).

\section{TGF- $\beta$-Mediated Inhibition of VIC Proliferation Is Prevented by Inhibitors to TGF- $\beta$ I}

As confirmed by intracellular labeling of the $p-S m a d 2 / 3$ complex (data not shown), TGF- $\beta$ signaling via the Smad path- 

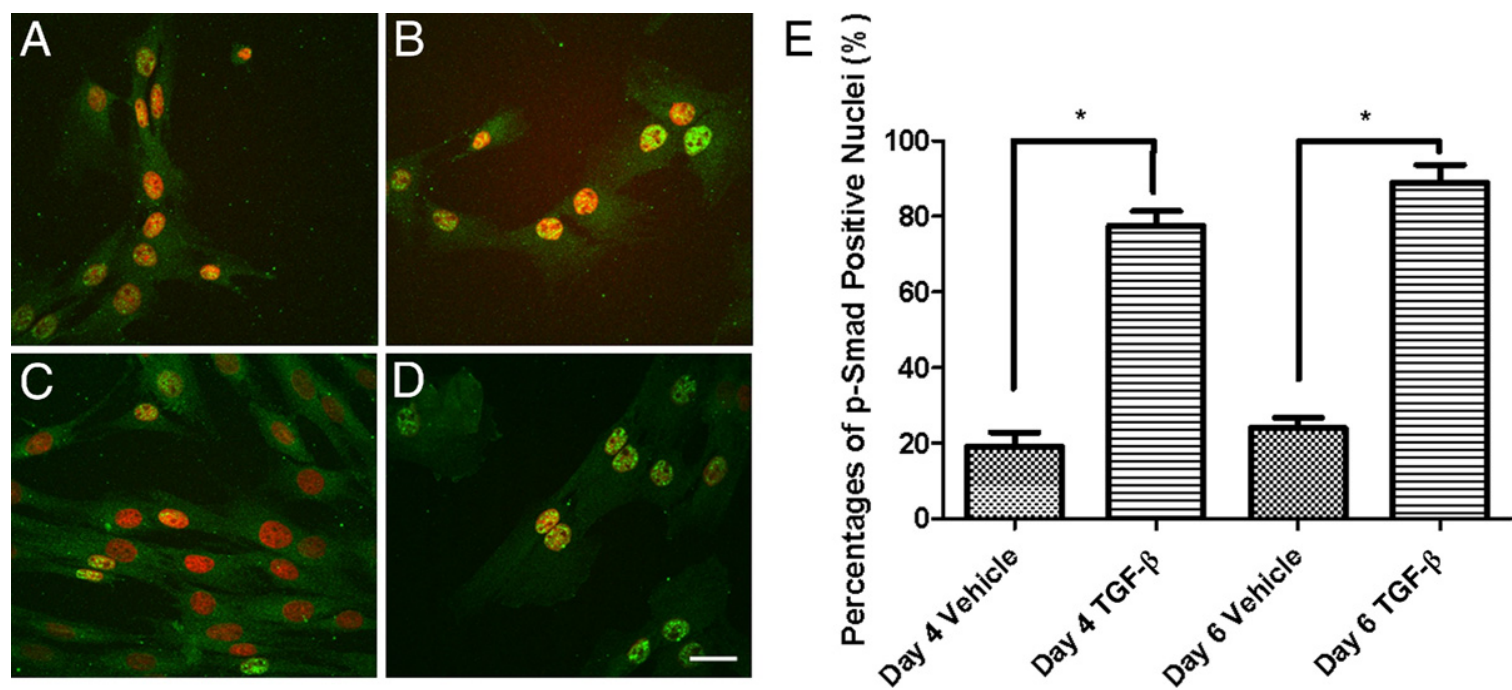

Figure 1. p-Smad in nuclei. Immunofluorescent confocal micrographs of vehicle (A and $\mathbf{C})$ and 5 ng/mL TGF- $\beta$-treated (B and $\mathbf{D})$ subconfluent VIC monolayers 4 days (A and $\mathbf{B}$ ) and 6 days $(\mathbf{C}$ and $\mathbf{D})$ after first TGF- $\beta$ addition are shown. VICs are stained for p-Smad2/3 (Ser $423 / 425$ ) (green; nuclei, red). There was more prominent p-Smad nuclear localization in treated VICs. Scale bar $=10 \mu \mathrm{m}(\mathbf{D})$. Original magnification, $\times 600$. E: Comparison of the percentages of p-Smadincorporated nuclei in vehicle and TGF- $\beta$-treated monolayers after 4 and 6 days. ${ }^{*} P<0.0001$ for statistical significance between groups. $n=9$.

way was effectively blocked by the inhibitor, SB431542. Because SB431542 functions by disrupting the kinase activity of TGF- $\beta$ RI, we incubated the cells with the inhibitor for 2 hours before adding any exogenous TGF- $\beta$ in an effort to block any of its downstream signaling. The inhibitory effect of TGF- $\beta$ was abolished in the presence of the inhibitor (Figure 3B)

We found that treatment with SB431542 alone without TGF- $\beta$ resulted in decreased cell growth (Figure $3 C$ ), and this growth-inhibitory effect was dose dependent. Maximal inhibition was observed at a concentration of 10 $\mu \mathrm{mol} / \mathrm{L}$. Another potent inhibitor of TGF- $\beta$ receptor, SD208, also inhibited VIC growth (data not shown). Using a neutralizing antibody to TGF- $\beta$ did not significantly affect VIC number (Figure 3D).

\section{TGF- $\beta$ Treatment Decreases Proliferation but Has No Effect on Apoptosis}

Replicating VICs incorporate BrdU into their newly synthesized DNA during a 6-hour incubation period with the base analog. TGF- $\beta$-treated VICs showed significantly fewer BrdU-stained nuclei (Figure 4, A-F). The percentages of BrdU-incorporated nuclei were counted, and the proliferation of TGF- $\beta$-treated VICs at 2 days (Figure 4G) and 4 days (Figure $4 \mathrm{H}$ ) after initial TGF- $\beta$ treatment was $9.4 \% \pm 0.4 \%$ and $16.1 \% \pm 0.7 \%$ lower than the control, respectively. Notably, even though the differences in cell number became significant after 4 days of treatment, proliferation rates started to differ at as early as 2 days after treatment. Because there was no significant difference in BrdU incorporation in VICs treated with 0.5 or 5 $\mathrm{ng} / \mathrm{mL}$ of TGF- $\beta$, a treatment concentration of $0.5 \mathrm{ng} / \mathrm{mL}$ was used in all experiments conducted thereafter. In TGF- $\beta$ - or vehicle-treated VICs, no apoptotic nuclei were observed (Figure 5, C and D). Apoptosis was also not observed in untreated confluent monolayers (data not shown).

\section{TGF- $\beta$ Treatment Leads to Hypophosphorylation of $p R b$ via Altered Expression of Cell Cycle}

\section{Proteins}

Alteration in the $\mathrm{pRb}$ phosphorylation status on specific residues (Ser807/811) is a critical regulatory step in $G_{1}$ to $S$ phase transition. The expression of phosphorylated $\mathrm{pRb}$ (Ser807/811) in both the cytoplasmic and nuclear compartments was significantly down-regulated by TGF- $\beta$ treatment (Figure 6A). Such an effect was reversed when the VICs were treated with SB431542 (Figure 6B).

The kinase complex responsible for the phosphorylation of $\mathrm{pRb}$ at Ser807/811 is the cyclin D1-CDK4 complex. ${ }^{32}$ TGF- $\beta$ treatment significantly decreased the expressions of both cyclin D1 and CDK4 (Figure 6C). At the same time, an inhibitor of the kinase complex, p27, was markedly up-regulated (Figure 6C). The differences in expression levels between groups are determined to be statistically significant (Figure 6, D-F).

\section{TGF- $\beta$ Treatment Alters VIC Morphological} Features and Increases VIC Adhesion to the

\section{Substratum}

TGF- $\beta$-treated VICs were rhomboid, as opposed to spindle shaped. They were flattened out on the substratum and larger at the same magnification. They also possessed more cellular protrusions. This change in VIC morphological features was reflected in the $\alpha$-SMA expression level (Figure 7, E and F) and localization at 4 days (Figure 7, A and B) and 6 days (Figure 7, C and D) after treatment. TGF- $\beta$-treated VICs showed more prominent and denser stress fiber when compared with the control.

Initially, in preparation for counting TGF- $\beta$-treated VICs, more incubation time in trypsin was required to fully 

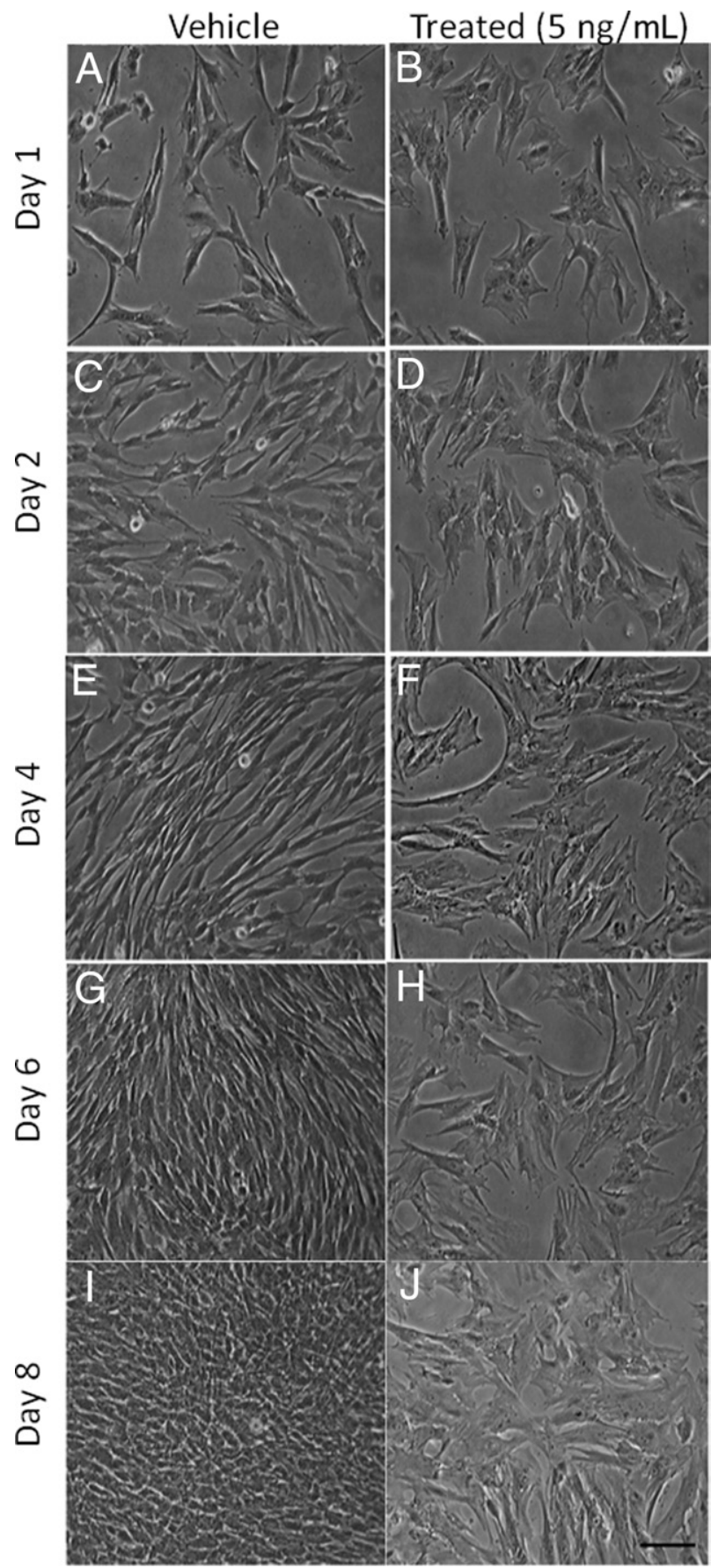

Figure 2. Phase-contrast micrographs of vehicle $(\mathbf{A}, \mathbf{C}, \mathbf{E}, \mathbf{G}$, and $\mathbf{I})$ and 5 ng/mL TGF- $\beta$-treated ( $\mathbf{B}, \mathbf{D}, \mathbf{F}, \mathbf{H}$, and $\mathbf{J}$ ) VICs taken 1 day (A and $\mathbf{B}$ ), 2 days $(\mathbf{C}$ and $\mathbf{D}), 4$ days $(\mathbf{E}$ and $\mathbf{F}), 6$ days $(\mathbf{G}$ and $\mathbf{H})$, and 8 days (I and $\mathbf{J})$ after initial treatment with TGF- $\beta$, showing the change over time in cell density and morphological features. Most treated cells appeared rhomboid, whereas the vehicle cells remained spindle shaped. Scale bar $=100 \mu \mathrm{m}(\mathbf{J})$. Original magnification, $\times 100$

detach from the substratum. The trypsin adhesion assay, which is designed to compare the degree of adhesion, revealed that TGF- $\beta$ treatment resulted in significantly fewer VICs becoming detached during the 0.5- or 1.0minute incubation period in diluted trypsin (Figure $8 \mathrm{C}$ ). More explicitly, after 4 days of TGF- $\beta$ treatment, VICs showed approximately eightfold stronger adhesion to the substratum. TGF- $\beta$ treatment also led to increased intensity of staining for vinculin, a surrogate for focal adhesion complex. As shown in Figure 8, A and B, TGF- $\beta$-treated VICs showed significantly more prominent vinculin plaques around the cell periphery when compared with the control, in which plaques were absent.

\section{Discussion}

To our knowledge, this is the first in vitro study to investigate the role of TGF- $\beta$ on VIC growth, independent of injury. We demonstrate that, in a subconfluent monolayer, exogenous TGF- $\beta$ decreases VIC proliferation by downregulation of cyclin D1 and CDK4, resulting in reduced phosphorylation of $\mathrm{pRb}$ and cell cycle arrest in the $\mathrm{G}_{1}$ phase. Our findings show that VICs are unique in being inhibited by TGF- $\beta$, unlike other fibroblasts in other tissues. Thus, for translational valve regeneration and tissue engineering studies, it is advisable to use VICs and not other fibroblast-type cells because the latter do not necessarily reflect the phenotype of VICs. Our in vitro findings and those of others will need to be validated in situ, where factors such as physical forces, inflammation, and physiological matrix are present.

TGF- $\beta$ is a highly versatile molecule that mediates a wide range of biological processes in several systems, and its cellular responses are known to be cell-type dependent. ${ }^{16}$ In the vascular system, TGF- $\beta$ inhibits the proliferation of endothelial cells while it stimulates that of the adjacent smooth muscle cells, ${ }^{33,34}$ despite their close proximity. Conversely, it has a pro-apoptotic effect on endothelial cells while being anti-apoptotic in smooth muscle cells. ${ }^{35}$ Overall, TGF- $\beta$ is recognized as a potent growth inhibitor in cells of epithelial origin ${ }^{36-41}$ and a growth stimulator in fibroblast-type cells. ${ }^{23,25,42}$ Although VICs are fibroblast-type cells, the anti-proliferative response in these fibroblasts could be partially explained by the fact that they are derived from surface endothelial cells that have undergone epithelial-to-mesenchymal transformation during embryonic development. ${ }^{2}$ It is possible that VICs from adult heart valves still possess characteristics of valve endothelial cells. In carefully considering our data, we suggest that, instead of categorizing the proliferative responses on the basis of cell type, studies should focus on the profile of activation of different downstream pathways and determine their individual contributions to the net results observed.

TGF- $\beta$ arrests the cell cycle in the $G_{1}$ phase, as demonstrated by decreased activity of thymidine kinase, a marker of cells entering the S phase. ${ }^{43}$ One key regulator of $G_{1}$ to $S$ phase transition is $p R b$, a growth suppressor that becomes functionally inactive when phosphorylated on specific residues. ${ }^{43-45}$ To confirm pRb under-phosphorylation as a result of TGF- $\beta$ stimulation, we examined the amount of phosphorylation on specific residues known to be involved in cell cycle regulation. The Ser807/ 811 site is phosphorylated by cyclin D1-CDK4 complexes, $^{32,46}$ and its phosphorylation status is examined in our study. We show that, in TGF- $\beta$-treated VICs, phosphorylated pRb (Ser807/811) is reduced by as much as 
A

TGF- $\beta$
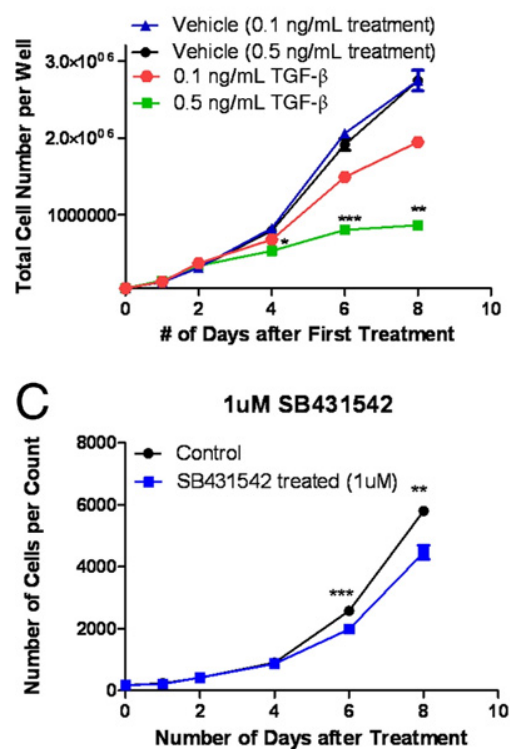

\section{B 2uM SB431542+5ng/mL TGF- $\beta$}
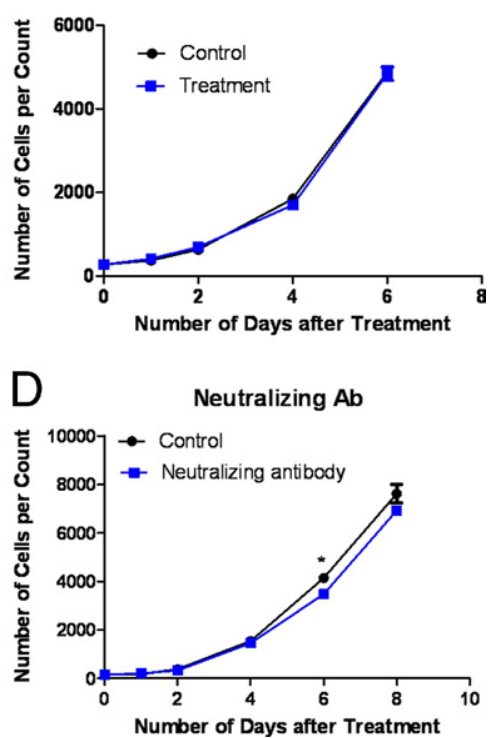

Figure 3. Growth curves of control and TGF- $\beta$-treated VICs. A: VIC growth in 0.1 or $0.5 \mathrm{ng} / \mathrm{mL}$ TGF- $\beta$ and corresponding vehicle-treated subconfluent monolayers. TGF- $\beta$ treated VICs showed significantly delayed growth after 4 days of treatment. The growth-inhibitory effect is concentration dependent because $0.5 \mathrm{ng} / \mathrm{mL}$ treatment resulted in a significantly greater extent of inhibition than $0.1 \mathrm{ng} / \mathrm{mL}$ treatment. (Only the statistical significance between the two treatment groups is shown.) B: VIC growth in two independent groups. In the control group, DMSO was added to the culture 2 hours before the addition of TGF- $\beta$ vehicle solution ( 4 $\mathrm{mmol} / \mathrm{L} \mathrm{HCl}$ and $0.1 \%$ bovine serum albumin). In the treatment group, $2 \mu \mathrm{mol} / \mathrm{L}$ SB 431542 was added to the culture 2 hours before the addition of $5 \mathrm{ng} / \mathrm{mL}$ TGF- $\beta$. The TGF- $\beta$ mediated growth inhibition is completely abolished in the presence of SB431542, and the two growth curves overlap. C: VIC growth in DMSO and $1 \mu \mathrm{mol} / \mathrm{L}$ SB 331542 treated subconfluent monolayers. The inhibitor alone inhibits VIC growth. D: VIC growth in vehicle- and TGF- $\beta$-neutralizing antibody (Ab)-treated monolayers. No significant change in cell number was observed. In all experiments, cell counts were performed in triplicate. Error bars denote SEM. Statistical significance between groups: ${ }^{*} P<0.05,{ }^{* *} P<0.01$, and ${ }^{* * * *} P<0.001$ 10-fold. As expected, there are concomitant decreases in the expression of both cyclin D1 and CDK4. P27 is an inhibitor of the kinase complex, ${ }^{47-50}$ and its expression is markedly up-regulated. Collectively, our data suggest that the control VICs are able to enter the S phase because of the presence of phosphorylated and inactive $\mathrm{pRb}$, which releases the transcription factor E2F to stimulate the production of DNA replication proteins. ${ }^{49,51,52}$ In
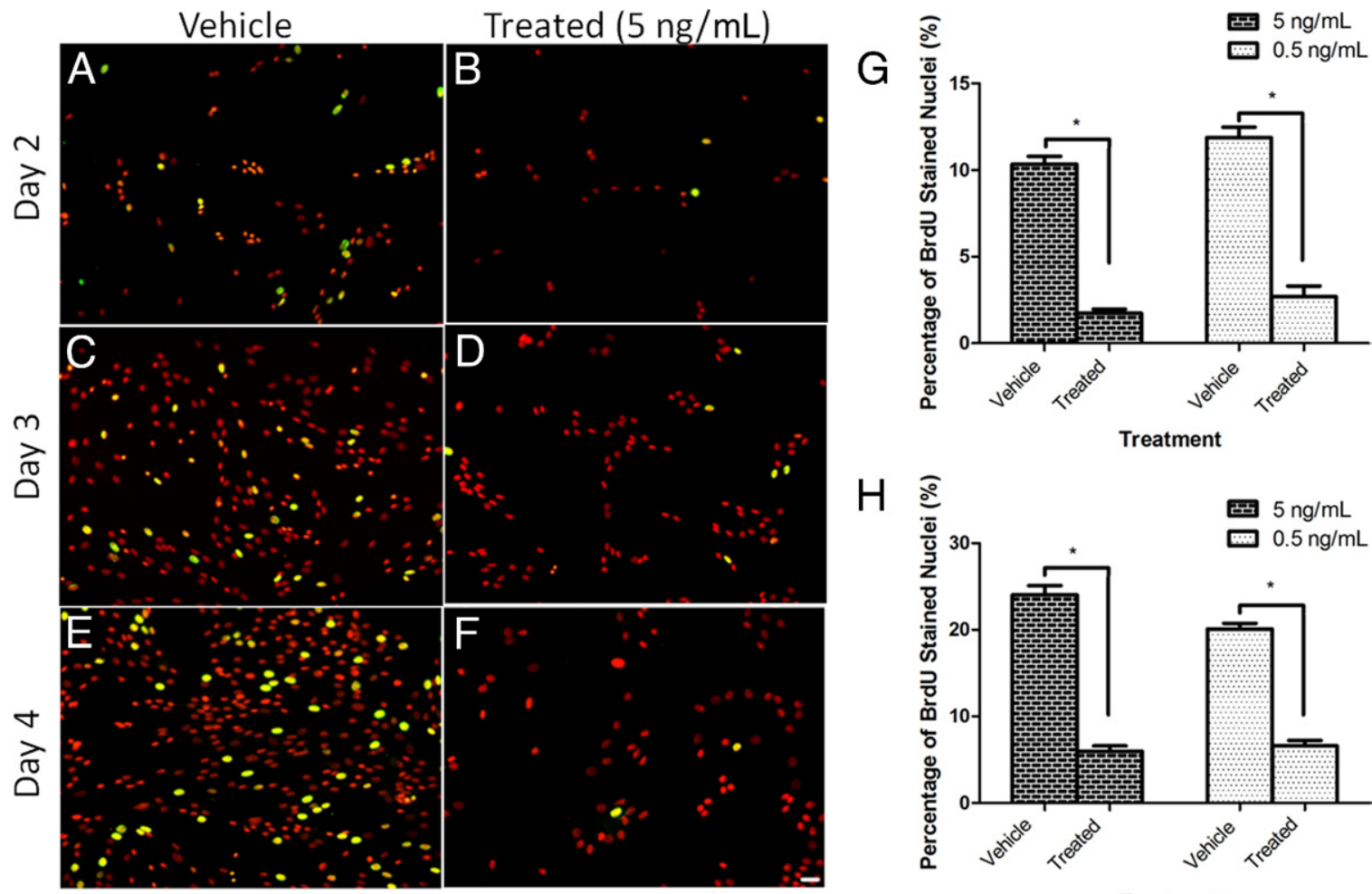

Treatment

Figure 4. BrdU incorporation in control and TGF- $\beta$-treated VICs. A comparison of the proportion of proliferating cells in vehicle $(\mathbf{A}, \mathbf{C}$, and $\mathbf{E})$ and $5 \mathrm{ng} / \mathrm{mI}$ TGF- $\beta$-treated $(\mathbf{B}, \mathbf{D}$, and $\mathbf{F})$ VICs 2 days $(\mathbf{A}$ and $\mathbf{B}), 3$ days $(\mathbf{C}$ and $\mathbf{D})$, and 4 days $(\mathbf{E}$ and $\mathbf{F})$ after first TGF- $\beta$ addition is shown in immunofluorescent micrographs of the nuclei of BrdU-incorporated VICs. Total nuclei are counterstained in red, with BrdU-stained nuclei shown in green. TGF- $\beta$ significantly decreases the proportion of proliferating cells in the treated monolayers $(\mathbf{B}, \mathbf{D}$, and $\mathbf{F})$. Scale bar $=10 \mu \mathrm{m}(\mathbf{F})$. Original magnification, $\times 200$. The percentages of proliferating cells in vehicle and $5 \mathrm{ng} / \mathrm{mL}$ or vehicle and $0.5 \mathrm{ng} / \mathrm{mL}$ TGF- $\beta$-treated subconfluent monolayers 2 days $(\mathbf{G})$ and 4 days $(\mathbf{H})$ after first TGF- $\beta$ addition are compared. TGF- $\beta$ at both concentrations tested significantly inhibits VIC proliferation at both time points. There is no significant difference in the percentages of proliferating cells treated with 5 and $0.5 \mathrm{ng} / \mathrm{mL}$ TGF- $\beta .{ }^{*} P<0.001$ denotes significant differences between groups. $n=15$. 

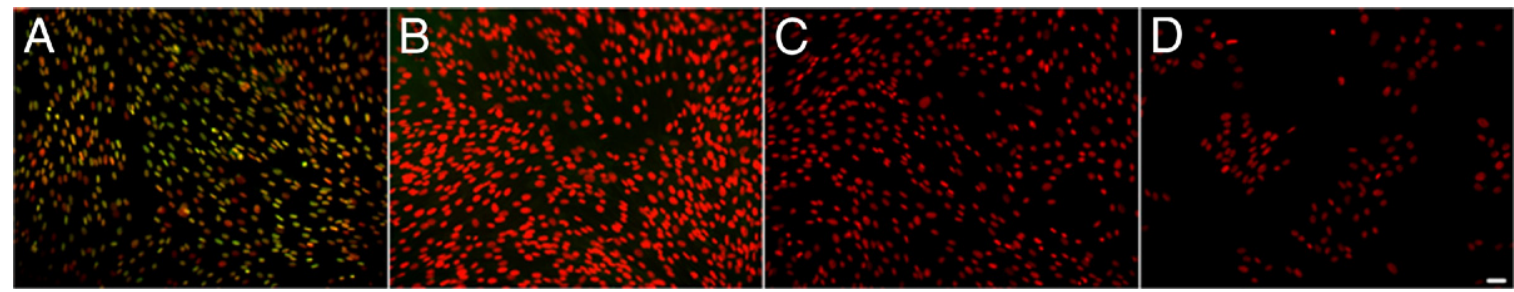

Figure 5. A-D: Immuofluorescent micrographs of the nuclei of apoptotic VICs 6 days after first TGF- $\beta$ treatment. Total nuclei are counterstained in red, with apoptotic nuclei shown in green. The positive control (A), with the addition of nuclease, shows a significant level of apoptosis, whereas the negative control (B), with the elimination of TdT enzyme, shows no sign of apoptosis; this is similar in the vehicle $(\mathbf{C})$ and $5 \mathrm{ng} / \mathrm{mL}$ TGF- $\beta$-treated VIC monolayers. Scale bar $=10$ $\mu \mathrm{m}$. Original magnification, $\times 200$.

contrast, TGF- $\beta$ R-phosphorylated Smad complexes translocate to the nucleus and associate with other transcription factors to directly modulate the promoter activity of CDK inhibitors. ${ }^{53,54}$ By associating with the cyclin D1CDK4 complexes and suppressing their kinase activity, these inhibitors are able to sequester the complexes in an inactive state. As a result of the combination effect of inhibitors and the direct TGF- $\beta$-mediated cyclin D1CDK4 down-regulation, treated VICs have mostly underphosphorylated active tumor suppressor proteins that contribute to the growth retardation. TGF- $\beta$ 's effect on phosphorylation is effectively reversed by a selective and potent inhibitor of TGF- $\beta$ RI, SB431542. By acting as an ATP mimetic, it disrupts the receptor kinase activity and abolishes TGF- $\beta$-mediated cellular responses in many cell types. ${ }^{28,55}$ Intriguingly, although this inhibitor is able to abolish the growth-suppressive effect of exogenous TGF- $\beta$, on its own, it decreases cell number without affecting cell survival. One likely explanation, as noted later, is that the various non-Smad pathways activated by TGF- $\beta$ may function independently to oppose the Smadmediated effects; in addition, the net cellular response depends on the extent of activation or suppression of each individual pathway. Inhibition of the entire TGF- $\beta$ signaling cascade rescues the Smad-mediated decrease in pRb phosphorylation. However, at the same time, suppression of the potentially proproliferative nonSmad pathways counteracts this effect, resulting in the observed counterintuitive growth inhibition by SB431542. Another less likely explanation is that SB431542 does relieve the $G_{1}$ to $S$ block. However, the inhibition itself may cause the arrest of the cell cycle at a different check point further downstream.

The outcome of TGF- $\beta$ action depends on cell type and local environment. This concept is best illustrated in the cancer literature. Depending on the combination effects of multiple factors in the tumor microenvironment (eg, the presence of other growth factors), immune cell population dynamics, and ECM composition, TGF- $\beta$ could either promote or suppress cancer progression and metastasis ${ }^{53,56,57}$ by altering the proliferative responses in the same cell line. In a previous study, ${ }^{8}$ we observed that TGF- $\beta$ expression is up-regulated on mechanical wounding and that, in response to injury, exog-
A

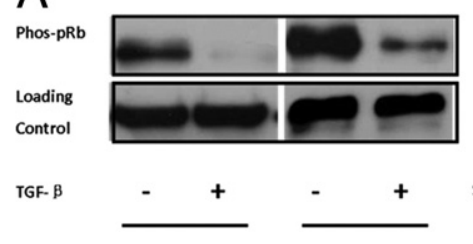

D

p-Rb Expression Following TGF- $\beta$ Treatment

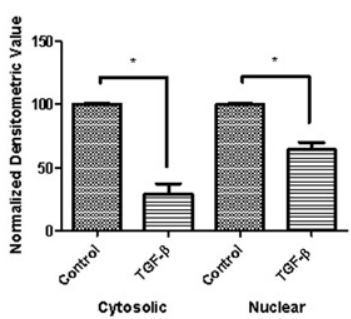

B
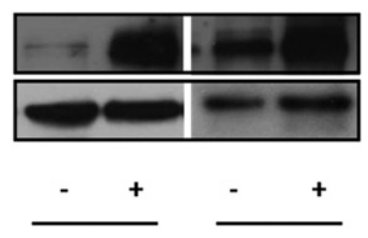

$\mathrm{E}$

p-Rb Expression Following SB431542 Treatment

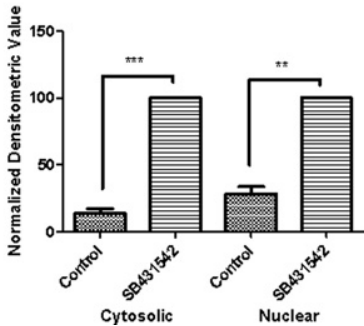

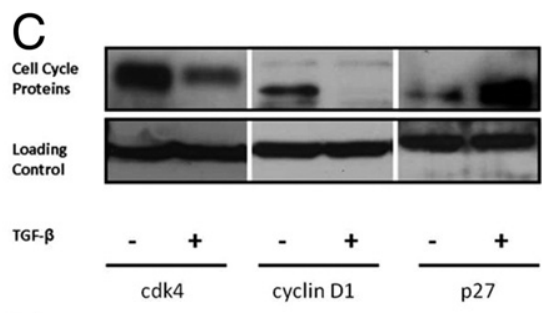

$\mathrm{F}$

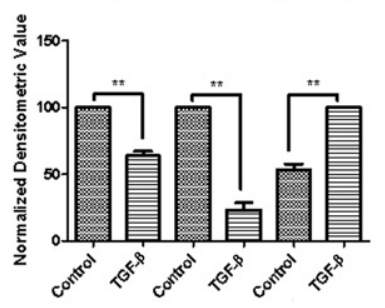

Figure 6. The expression levels of phosphorylated pRb (Ser 807/811) in the cytoplasm and nucleus of vehicle and $0.5 \mathrm{ng} / \mathrm{mL}$ TGF- $\beta$-treated VICs (A) and vehicle and $5 \mu \mathrm{mol} / \mathrm{L}$ SB431542-treated VICs (B) are determined using Western blot analyses. Cell extracts were prepared 6 days after first TGF- $\beta$ treatment. Extracts containing $20 \mu \mathrm{g}$ of protein were separated on an $8 \%$ polyacrylamide gel. C: Expression of whole cell CDK4, cyclin D1, and nuclear p27 in vehicle and $0.5 \mathrm{ng} / \mathrm{mL}$ TGF- $\beta$-treated VICs. Cell extracts were prepared 6 days after first TGF- $\beta$ treatment. Extracts containing $40 \mu \mathrm{g}$ of protein were separated on a $12.5 \%$ polyacrylamide gel. Phosphorylated pRb, CDK4, cyclin D1, p27, and their corresponding loading controls (tubulin and histone) were detected by immunoblotting. D-F: The levels of expression are determined by densitometry and compared. Statistical significance between groups: ${ }^{*} P<0.01,{ }^{* * *} P<0.001$, and ${ }^{* * * *} P<0.0001$. 

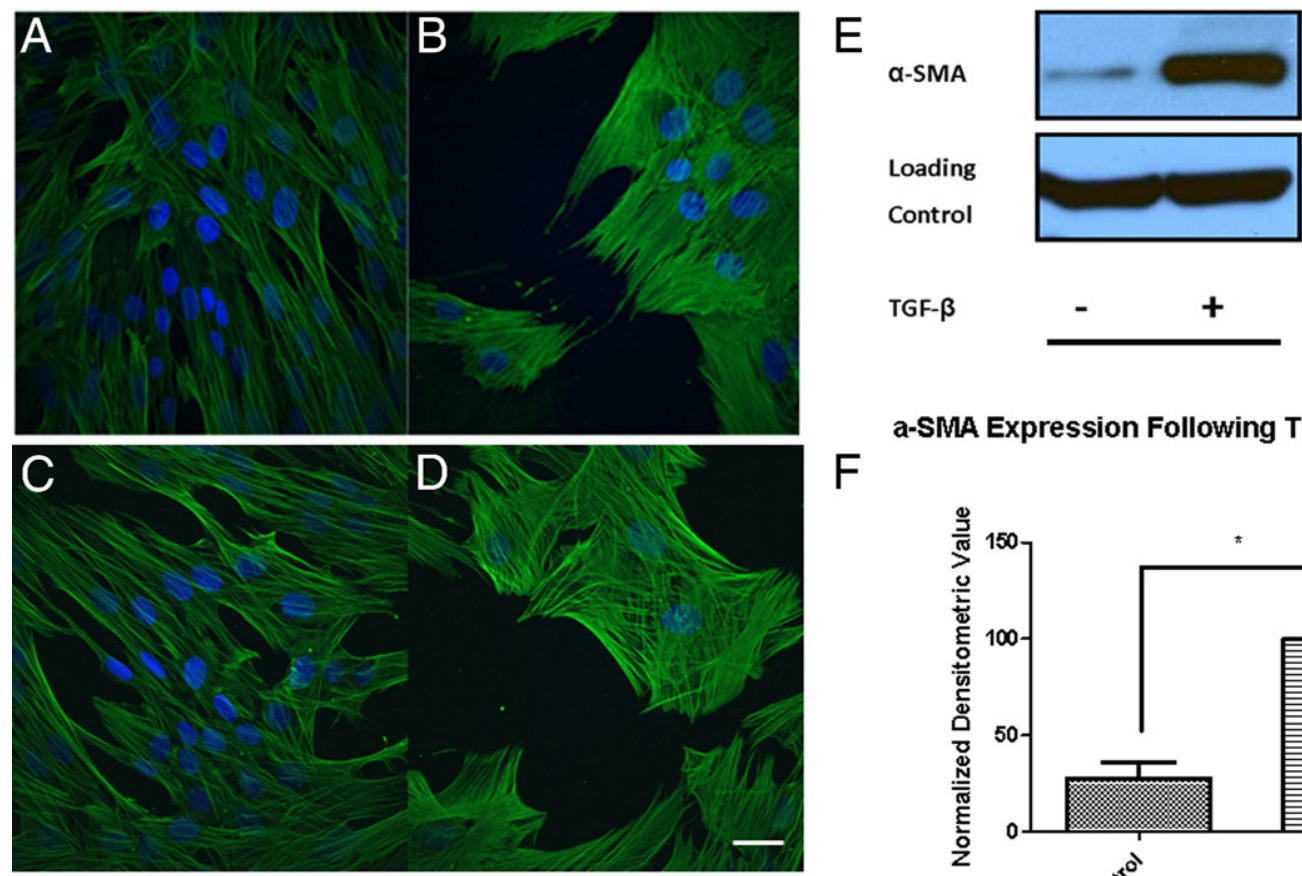

\section{a-SMA Expression Following TGF- $\beta$ Treatment}

$\mathrm{F}$

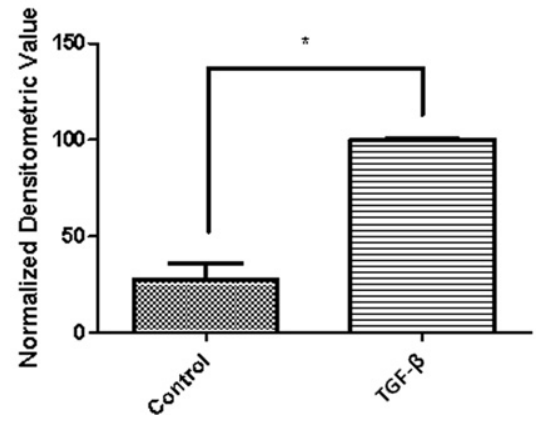

Figure 7. $\alpha$-SMA expression in control and TGF- $\beta$-treated VICs. Immunofluorescent confocal micrographs of vehicle and 5 ng/mL TGF- $\beta$-treated subconfluent VIC monolayers 4 days (A and $\mathbf{B})$ and 6 days $(\mathbf{C}$ and $\mathbf{D})$ after first TGF- $\beta$ addition are shown. VICs are stained for $\alpha$-SMA, which is expressed at a much higher level and organized into stress fibers in the treated group (green; nuclei, blue). Scale bar $=10 \mu \mathrm{m}(\mathbf{D})$. Original magnification, $\times 600$. E: Expression of whole cell $\alpha$-SMA in vehicle and $0.5 \mathrm{ng} / \mathrm{mL}$ TGF- $\beta$-treated VICs. Cell extracts were prepared 6 days after first TGF- $\beta$ treatment. Extracts containing $10 \mu \mathrm{g}$ of protein were separated on an $8 \%$ polyacrylamide gel. $\alpha$-SMA and tubulin loading control were detected by immunoblotting. F: The levels of expression in control and treated VICs are determined by densitometry and compared. ${ }^{*} P<0.001$ denotes statistical significance between groups.

enous TGF- $\beta$ promotes VIC proliferation while it inhibits apoptosis in the early stage of wound repair. In contrast to what was reported at the wound edge, this current study shows that TGF- $\beta$ decreases proliferation in lowdensity monolayers, independent of injury. The culture conditions used in this present study and the previously published wound model study are the same, suggesting that the differences observed are not a result of an in vitro artifact. Instead, one possibility is that mechanical wounding is an external stimulus that alters the signaling profile of quiescent VICs, leading to different cellular responses. Under both conditions and in essentially all cell types, the Smad signaling pathway is activated in the presence of TGF- $\beta$. In other words, the same Smad molecules are up-regulated in all cellular and molecular contexts. Therefore, it is unlikely that Smad alone could mediate the full spectrum of TGF- $\beta$-related responses observed. In fact, TGF- $\beta$ has activated many Smad-independent pathways, such as the mitogen-activated protein kinase, $\rho$-like Rho-GTPase, and PI3K-AKT pathways. ${ }^{15}$ One possibility is that one of these pathways may function independent of Smad and elicit opposing downstream effects. However, their signaling mechanisms and direct impacts on cell proliferation remain to be eluci-
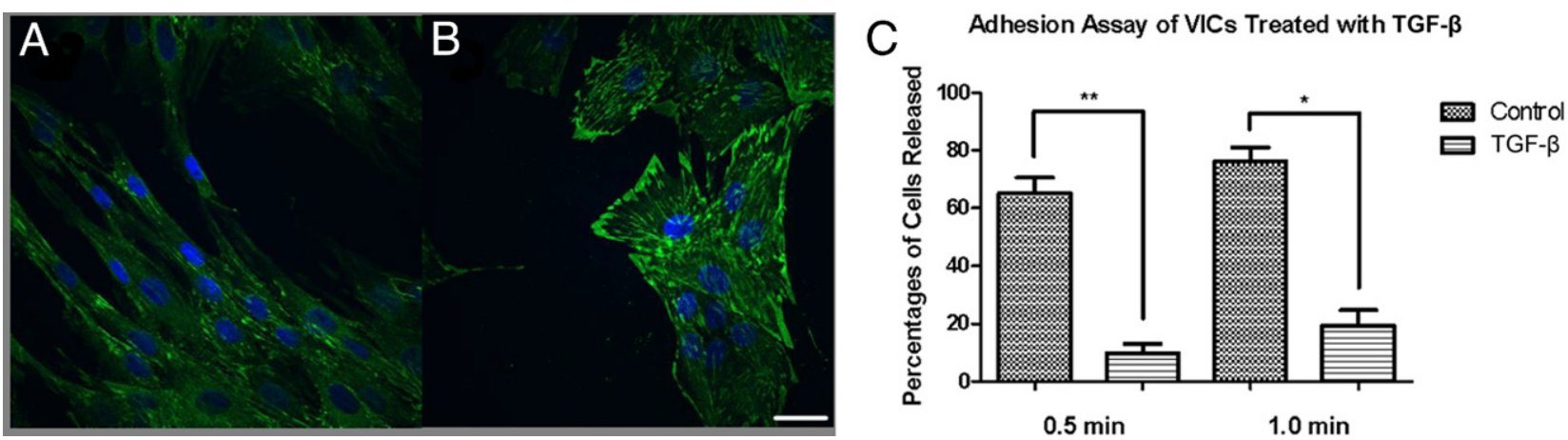

Figure 8. VIC adhesion in control and TGF- $\beta$-treated VICs. Immunofluorescent confocal micrographs of vehicle (A) and 5 ng/mL TGF- $\beta$-treated (B) subconfluent VIC monolayers 4 days after first TGF- $\beta$ addition are shown. VICs are stained for vinculin (green; nuclei, blue), which is expressed at a higher level and organized into vinculin plaques in the treated group. Scale bar $=10 \mu \mathrm{m}(\mathbf{B})$. Original magnification, $\times 600$. C: Results from the trypsin adhesion assay showing proportions of cells detached during the given incubation period. TGF- $\beta$-treated VICs showed significantly greater attachment to the substratum. Three independent trials were performed. Error bars denote SEM. Statistical significance between groups: ${ }^{*} P<0.01,{ }^{* * *} P<0.001$ 
dated. In one study, ${ }^{58}$ it was suggested that the activation of the PI3K pathway is only observed in fibroblast cell lines in response to TGF- $\beta$ stimulation, but not in epithelial cells, resulting in growth promotion in fibroblasts but inhibition in epithelial cells. One hypothesis is that VICs process different external stimuli and modulate the levels of the anti-proliferative Smad signaling and the pro-proliferative PI3K signaling to achieve the most desirable outcome. The net result of this active modulation is either VIC proliferation or wound closure in response to injury or growth inhibition under physiological conditions to prevent overgrowth and disruption of the valve structure. To design in vitro models that best replicate the in vivo conditions, every potential external stimulus and interaction should be considered. However, for the study of molecules with complex signaling cascades, such as TGF- $\beta$, it is more reasonable to start from the most basic system with few confounding variables and gradually build up the network of interactions. In this study of VIC growth regulation, we show that TGF- $\beta$ has growth-inhibitory effects on intact monolayers. However, when an external stimulus, such as mechanical wounding, is applied to this system, VICs respond to the same molecule differently, likely by modulating the levels of activation of various downstream signaling pathways. Therefore, selectively determining the impact of each stimulus on the signaling profile is important in understanding the context-dependent effect of TGF- $\beta$ under various conditions.

We also show that TGF- $\beta$ addition leads to increased formation of $\alpha$-SMA stress fibers and vinculin plaques, which may be a secondary effect of reduced growth or a condition that limits proliferation. In addition to a reduction in cell number, $0.5 \mathrm{ng} / \mathrm{mL}$ of TGF- $\beta$ is sufficient to cause a significant increase in adhesion and a morphological change from spindle to rhomboid shaped after 4 days of treatment. Although TGF- $\beta$ directly regulates cell cycle progression through several well-characterized mechanisms, ${ }^{37,39,40,59}$ decreased VIC proliferation can equally be attributed to increased cell-ECM adhesion and cytoskeletal rearrangement. ${ }^{60}$ Consistent with our previous study ${ }^{61}$ of single VICs, the rhomboid cells that arise from TGF- $\beta$ treatment show stronger attachments. They also possess abundant $\alpha$-SMA stress fibers that, in turn, correlate with increased adherence. ${ }^{62}$ As a result, treated VICs require more time to physically round up from the substratum and proliferate. It is critical to recognize the bidirectionality of cell-matrix signaling. In addition to various ECM remodeling processes coordinated by signals transmitted or factors released from the cell, there is also matrix-to-cell signaling. In general, cell morphological features, cytoskeleton-matrix force transmission, adhesion, and matrix stiffness are all interrelated, and they act in concert to control the growth and differentiation of cells. ${ }^{63-65}$

In summary, our two major findings are that TGF- $\beta$ regulation of VIC growth is context dependent and that TGF- $\beta$ inhibits VIC proliferation, similar to effects on epithelial, but not fibroblast-type, cells.

\section{Acknowledgment}

We thank Dr. Alan Rosenthal for technical assistance.

\section{References}

1. Lester W, Rosenthal A, Granton B, Gotlieb Al: Porcine mitral valve interstitial cells in culture. Lab Invest 1988, 59:710-719

2. Liu AC, Joag VR, Gotlieb Al: The emerging role of valve interstitial cell phenotypes in regulating heart valve pathobiology. Am J Pathol 2007 , 171:1407-1418

3. Mulholland DL, Gotlieb Al: Cell biology of valvular interstitial cells Can J Cardiol 1996, 12:231-236

4. Filip DA, Radu A, Simionescu M: Interstitial cells of the heart valves possess characteristics similar to smooth muscle cells. Circ Res 1986, 59:310-320

5. Taylor PM, Batten P, Brand NJ, Thomas PS, Yacoub MH: The cardiac valve interstitial cell. Int J Biochem Cell Biol 2003, 35:113-118

6. Durbin AD, Gotlieb Al: Advances towards understanding heart valve response to injury. Cardiovasc Pathol 2002, 11:69-77

7. Rabkin-Aikawa E, Farber M, Aikawa M, Schoen FJ: Dynamic and reversible changes of interstitial cell phenotype during remodeling of cardiac valves. J Heart Valve Dis 2004, 13:841-847

8. Liu AC, Gotlieb Al: Transforming growth factor-beta regulates in vitro heart valve repair by activated valve interstitial cells. Am J Pathol 2008, 173:1275-1285

9. Gabbiani G: The myofibroblast in wound healing and fibrocontractive diseases. J Pathol 2003, 200:500-503

10. Fayet C, Bendeck MP, Gotlieb Al: Cardiac valve interstitial cells secrete fibronectin and form fibrillar adhesions in response to injury. Cardiovasc Pathol 2007, 16:203-211

11. Lester WM, Damji AA, Tanaka M, Gedeon I: Bovine mitral valve organ culture: role of interstitial cells in repair of valvular injury. $\mathrm{J}$ Mol Cell Cardiol 1992, 24:43-53

12. Werner S, Grose R: Regulation of wound healing by growth factors and cytokines. Physiol Rev 2003, 83:835-870

13. Roberts AB, Anzano MA, Wakefield LM, Roche NS, Stern DF, Sporn MB: Type beta transforming growth factor: a bifunctional regulator of cellular growth. Proc Natl Acad Sci U S A 1985, 82:119-123

14. Shi $\mathrm{Y}$, Massague J: Mechanisms of TGF-beta signaling from cell membrane to the nucleus. Cell 2003, 113:685-700

15. Zhang YE: Non-Smad pathways in TGF-beta signaling. Cell Res 2009, 19:128-139

16. Heldin $\mathrm{CH}$, Landstrom M, Moustakas A: Mechanism of TGF-beta signaling to growth arrest, apoptosis, and epithelial-mesenchymal transition. Curr Opin Cell Biol 2009, 21:166-176

17. Border WA, Ruoslahti E: Transforming growth factor-beta in disease: the dark side of tissue repair. J Clin Invest 1992, 90:1-7

18. Hinton RB Jr, Lincoln J, Deutsch GH, Osinska H, Manning PB, Benson DW, Yutzey KE: Extracellular matrix remodeling and organization in developing and diseased aortic valves. Circ Res 2006, 98:14311438

19. Jian B, Narula N, Li QY, Mohler ER 3rd, Levy RJ: Progression of aortic valve stenosis: TGF-beta1 is present in calcified aortic valve cusps and promotes aortic valve interstitial cell calcification via apoptosis. Ann Thorac Surg 2003, 75:457-465; discussion 465-466

20. Ng CM, Cheng A, Myers LA, Martinez-Murillo F, Jie C, Bedja D, Gabrielson KL, Hausladen JM, Mecham RP, Judge DP, Dietz HC: TGF-beta-dependent pathogenesis of mitral valve prolapse in a mouse model of Marfan syndrome. J Clin Invest 2004, 114:15861592

21. Rabkin E, Aikawa M, Stone JR, Fukumoto $Y$, Libby P, Schoen FJ: Activated interstitial myofibroblasts express catabolic enzymes and mediate matrix remodeling in myxomatous heart valves. Circulation 2001, 104:2525-2532

22. Matt P, Schoenhoff F, Habashi J, Holm T, Van Erp C, Loch D, Carlson OD, Griswold BF, Fu Q, De Backer J, Loeys B, Huso DL, McDonnell $N B$, Van Eyk JE, Dietz HC: Circulating transforming growth factorbeta in Marfan syndrome. Circulation 2009, 120:526-532

23. Battegay EJ, Raines EW, Seifert RA, Bowen-Pope DF, Ross R: TGFbeta induces bimodal proliferation of connective tissue cells via complex control of an autocrine PDGF loop. Cell 1990, 63:515-524 
24. Zhou W, Park I, Pins M, Kozlowski JM, Jovanovic B, Zhang J, Lee C, Ilio K: Dual regulation of proliferation and growth arrest in prostatic stromal cells by transforming growth factor-beta1. Endocrinology 2003, 144:4280-4284

25. Lee KY, Bae SC: TGF-beta-dependent cell growth arrest and apoptosis. J Biochem Mol Biol 2002, 35:47-53

26. Heredia A, Villena J, Romaris M, Molist A, Bassols A: The effect of TGF-beta 1 on cell proliferation and proteoglycan production in human melanoma cells depends on the degree of cell differentiation. Cancer Lett 1996, 109:39-47

27. Inman GJ, Nicolás FJ, Callahan JF, Harling JD, Gaster LM, Reith AD, Laping NJ, Hill CS: SB-431542 is a potent and specific inhibitor of transforming growth factor-beta superfamily type I activin receptorlike kinase (ALK) receptors ALK4, ALK5, and ALK7. Mol Pharmacol 2002, 62:65-74

28. Watabe T, Nishihara A, Mishima K, Yamashita J, Shimizu K, Miyazawa K, Nishikawa S, Miyazono K: TGF-beta receptor kinase inhibitor enhances growth and integrity of embryonic stem cell-derived endothelial cells. J Cell Biol 2003, 163:1303-1311

29. Halder SK, Beauchamp RD, Datta PK: A specific inhibitor of TGF-beta receptor kinase, SB-431542, as a potent antitumor agent for human cancers. Neoplasia 2005, 7:509-521

30. Uhl M, Aulwurm S, Wischhusen J, Weiler M, Ma JY, Almirez R, Mangadu R, Liu YW, Platten M, Herrlinger U, Murphy A, Wong DH, Wick W, Higgins LS, Weller M: SD-208, a novel transforming growth factor beta receptor I kinase inhibitor, inhibits growth and invasiveness and enhances immunogenicity of murine and human glioma cells in vitro and in vivo. Cancer Res 2004, 64:7954-7961

31. Zacks S, Rosenthal A, Granton B, Havenith M, Opas M, Gotlieb Al: Characterization of Cobblestone mitral valve interstitial cells. Arch Pathol Lab Med 1991, 115:774-779

32. Zarkowska T, Mittnacht S: Differential phosphorylation of the retinoblastoma protein by G1/S cyclin-dependent kinases. J Biol Chem 1997, 272:12738-12746

33. Ghosh J, Murphy MO, Turner N, Khwaja N, Halka A, Kielty CM, Walker MG: The role of transforming growth factor beta1 in the vascular system. Cardiovasc Pathol 2005, 14:28-36

34. Kobayashi K, Yokote K, Fujimoto M, Yamashita K, Sakamoto A, Kitahara M, Kawamura H, Maezawa Y, Asaumi S, Tokuhisa T, Mori S, Saito Y: Targeted disruption of TGF-beta-Smad3 signaling leads to enhanced neointimal hyperplasia with diminished matrix deposition in response to vascular injury. Circ Res 2005, 96:904-912

35. Pollman MJ, Naumovski L, Gibbons GH: Vascular cell apoptosis: cell type-specific modulation by transforming growth factor-beta1 in endothelial cells versus smooth muscle cells. Circulation 1999, 99: 2019-2026

36. Geng H, Lan R, Wang G, Siddiqi AR, Naski MC, Brooks Al, Barnes JL, Saikumar P, Weinberg JM, Venkatachalam MA: Inhibition of autoregulated TGFbeta signaling simultaneously enhances proliferation and differentiation of kidney epithelium and promotes repair following renal ischemia. Am J Pathol 2009, 174:1291-1308

37. Pietenpol JA, Holt JT, Stein RW, Moses HL: Transforming growth factor beta 1 suppression of c-myc gene transcription: role in inhibition of keratinocyte proliferation. Proc Natl Acad Sci U S A 1990, 87:3758-3762

38. Sandhu C, Garbe J, Bhattacharya N, Daksis J, Pan CH, Yaswen P, Koh J, Slingerland JM, Stampfer MR: Transforming growth factor beta stabilizes p15INK4B protein, increases p15INK4B-cdk4 complexes, and inhibits cyclin D1-cdk4 association in human mammary epithelial cells. Mol Cell Biol 1997, 17:2458-2467

39. Schlegel NC, Eichhoff OM, Hemmi S, Werner S, Dummer R, Hoek KS: Id2 suppression of p15 counters TGF-beta-mediated growth inhibition of melanoma cells. Pigment Cell Melanoma Res 2009, 22 : 445-453

40. Spender LC, Inman GJ: TGF-beta induces growth arrest in Burkitt lymphoma cells via transcriptional repression of E2F-1. J Biol Chem 2009, 284:1435-1442

41. Wang X, Sun W, Bai J, Ma L, Yu Y, Geng J, Qi J, Shi Z, Fu S: Growth inhibition induced by transforming growth factor-beta1 in human oral squamous cell carcinoma. Mol Biol Rep 2009, 36:861-869

42. Rahimi RA, Andrianifahanana M, Wilkes MC, Edens M, Kottom TJ, Blenis J, Leof EB: Distinct roles for mammalian target of rapamycin complexes in the fibroblast response to transforming growth factor-beta. Cancer Res 2009, 69:84-93

43. Furukawa Y, Uenoyama S, Ohta M, Tsunoda A, Griffin JD, Saito M: Transforming growth factor-beta inhibits phosphorylation of the retinoblastoma susceptibility gene product in human monocytic leukemia cell line JOSK-I. J Biol Chem 1992, 267:17121-17127

44. Herrera RE, Makela TP, Weinberg RA: TGF beta-induced growth inhibition in primary fibroblasts requires the retinoblastoma protein. Mol Biol Cell 1996, 7:1335-1342

45. Laiho M, DeCaprio JA, Ludlow JW, Livingston DM, Massague J: Growth inhibition by TGF-beta linked to suppression of retinoblastoma protein phosphorylation. Cell 1990, 62:175-185

46. Hochegger H, Takeda S, Hunt T: Cyclin-dependent kinases and cell-cycle transitions: does one fit all? Nat Rev Mol Cell Biol 2008 , 9:910-916

47. Kim HP, Kim TY, Lee MS, Jong HS, Kim TY, Lee JW, Bang YJ: TGF-beta1-mediated activations of $\mathrm{C}-\mathrm{Src}$ and Rac1 modulate levels of cyclins and p27(Kip1) CDK inhibitor in hepatoma cells replated on fibronectin. Biochim Biophys Acta 2005, 1743:151-161

48. Lecanda J, Ganapathy V, D'Aquino-Ardalan C, Evans B, Cadacio C, Ayala A, Gold LI: TGFbeta prevents proteasomal degradation of the cyclin-dependent kinase inhibitor p27kip1 for cell cycle arrest. Cell Cycle 2009, 8:742-756

49. Nevins JR: The Rb/E2F pathway and cancer. Hum Mol Genet 2001, 10:699-703

50. Polyak K, Kato JY, Solomon MJ, Sherr CJ, Massague J, Roberts JM, Koff A: p27Kip1, a cyclin-Cdk inhibitor, links transforming growth factor-beta and contact inhibition to cell cycle arrest. Genes Dev 1994, 8:9-22

51. Dyson N: The regulation of E2F by pRB-family proteins. Genes Dev 1998, 12:2245-2262

52. Takahashi $Y$, Rayman JB, Dynlacht BD: Analysis of promoter binding by the E2F and pRB families in vivo: distinct E2F proteins mediate activation and repression. Genes Dev 2000, 14:804-816

53. Massague J: TGFbeta in cancer. Cell 2008, 134:215-230

54. Moustakas A, Pardali K, Gaal A, Heldin CH: Mechanisms of TGF-beta signaling in regulation of cell growth and differentiation. Immunol Lett 2002, 82:85-91

55. Hjelmeland MD, Hjelmeland AB, Sathornsumetee S, Reese ED, Herbstreith MH, Laping NJ, Friedman HS, Bigner DD, Wang XF, Rich JN: SB-431542, a small molecule transforming growth factor-beta-receptor antagonist, inhibits human glioma cell line proliferation and motility. Mol Cancer Ther 2004, 3:737-745

56. Bierie B, Moses HL: Tumour microenvironment: TGFbeta: the molecular Jekyll and Hyde of cancer. Nat Rev Cancer 2006, 6:506-520

57. Stover DG, Bierie B, Moses HL: A delicate balance: TGF-beta and the tumor microenvironment. J Cell Biochem 2007, 101:851-861

58. Wilkes MC, Mitchell H, Penheiter SG, Dore JJ, Suzuki K, Edens M, Sharma DK, Pagano RE, Leof EB: Transforming growth factor-beta activation of phosphatidylinositol 3-kinase is independent of Smad2 and Smad3 and regulates fibroblast responses via p21-activated kinase-2. Cancer Res 2005, 65:10431-10440

59. Datto MB, Li Y, Panus JF, Howe DJ, Xiong Y, Wang XF: Transforming growth factor beta induces the cyclin-dependent kinase inhibitor p21 through a p53-independent mechanism. Proc Natl Acad Sci U S A 1995, 92:5545-5549

60. Rout UK, Saed GM, Diamond MP: Transforming growth factor-beta1 modulates expression of adhesion and cytoskeletal proteins in human peritoneal fibroblasts. Fertil Steril 2002, 78:154-161

61. Liu AC, Gotlieb Al: Characterization of cell motility in single heart valve interstitial cells in vitro. Histol Histopathol 2007, 22:873-882

62. Blevins TL, Carroll JL, Raza AM, Grande-Allen KJ: Phenotypic characterization of isolated valvular interstitial cell subpopulations. J Heart Valve Dis 2006, 15:815-822

63. Chen CS, Tan J, Tien J: Mechanotransduction at cell-matrix and cell-cell contacts. Annu Rev Biomed Eng 2004, 6:275-302

64. Li C, Xu S, Gotlieb Al: The response to valve injury: a paradigm to understand the pathogenesis of heart valve disease. Cardiovasc Pathol 2011, 20:183-190

65. Mammoto A, Ingber DE: Cytoskeletal control of growth and cell fate switching. Curr Opin Cell Biol 2009, 21:864-870 